\title{
Linking fisheries management and conservation in bioengineering species: the case of South American mussels (Mytilidae)
}

\author{
Alvar Carranza · Omar Defeo · Mike Beck • \\ Juan Carlos Castilla
}

Received: 25 July 2008/Accepted: 30 January 2009/Published online: 3 February 2009

(C) The Author(s) 2009. This article is published with open access at Springerlink.com

\begin{abstract}
We examined a complete list of South American mussels (Mytilidae) to identify species with current or potential needs for management and conservation actions. Based on ecological/ecosystem (aggregations, beds or banks affecting ecosystem functioning) and socio-economic (artisanal fisheries or aquaculture systems) attributes species with high relevance were identified. At least 14 species exhibited large ecosystem level effects at local scales. Further, most of them also sustain important fisheries: nearly one/third of these fisheries showed characteristics that may contribute to their lack of sustainability and overexploitation, while half are either in the initial exploitation phase or in the
\end{abstract}

A. Carranza $(\bowtie) \cdot$ O. Defeo

UNDECIMAR, Facultad de Ciencias, Iguá 4225,

CP11400 Montevideo, Uruguay

e-mail: alvardoc@fcien.edu.uy

A. Carranza $\cdot$ O. Defeo

DINARA, Constituyente 1497, 11200 Montevideo,

Uruguay

M. Beck

The Nature Conservancy and Institute of Marine Sciences, University of California, 100 Shaffer Road, LML,

Santa Cruz, CA 95060, USA

J. C. Castilla

Centro de Estudios Avanzados en Ecología \&

Biodiversidad, Facultad de Ciencias Biológicas, Pontificia

Universidad Católica de Chile, Casilla 114-D,

Santiago, Chile stabilization of extraction and institutionalization phase. Invading species are modifying the structure of mussel habitats. Allocation of spatially explicit management tools, notably Territorial User Rights in Fisheries and Marine Reserves, together with comanagement initiatives, are suggested as relevant tools to fulfill management and conservation objectives for these key bioengineering species.

Keywords Mytilus Brachidontes .

Choromytilus $\cdot$ Mytella $\cdot$ Co-management

\section{Introduction}

Marine coastal ecosystems in South America are experiencing increasing anthropogenic impacts, such as habitat transformation, fragmentation or destruction, introduction or extinction of organisms, resource depletion and food-web modifications (Castilla 1999; Castilla et al. 2005; Castilla and Neill 2009). In these systems, the loss of ecosystem engineers may be especially critical, because they increase the structural complexity of the habitat, enhance local biomass and biodiversity, and control critical processes (e.g., Coleman and Williams 2002). Thus, the decline of these species may have cascading effects on ecosystem structure and functioning (e.g., Norling and Kautsky 2007).

Mussels have an outstanding functional role in most marine intertidal and shallow shelf environments, 
providing a wide variety of ecosystem services (Bayne 1976; Smaal 1991; Norling and Kautsky 2007). These bivalves are classic ecosystem engineers (Jones et al. 1994), because they generate structures that persist for long periods and strongly affect many ecosystem processes and services (e.g., water quality through filtration). Their effects on local species richness at local and regional scales are thus presumably high, since they provide tri-dimensional structures that offer enemy or stress-free space for a plethora of fish, invertebrate and algae species (Thiel and Ullrich 2002; Prado and Castilla 2006; Borthagaray and Carranza 2007).

Significant declines in the extent of wild intertidal mussel beds have been reported from large coastal areas in Europe (e.g., Germany, the Netherlands and Denmark). In particular, Mytilus edulis beds have suffered strong declines in the Wadden Sea (Germany and Netherlands) and are threatened in the United Kingdom (OSPAR Commission 2005; Wolff 2005). In South Africa, there are problems of mussel overexploitation, and management and conservation measures have been suggested (Hockey and Bosman 1986; Lasiak and Dye 1989). Empirical evidence showed that the intensity of human harvest, in conjunction with high accessibility to sites, is one of the main factors affecting mussel substratum cover and individual mean sizes (e.g., Rius and Cabral
2004). The presence of high densities of mussels associated with artificial hard coastal defence structures, which can affect the shoreline, appears as a general trend in some European countries (Airoldi et al. 2005a). However, even in these artificial habitats, harvesting of mussels is particularly disruptive and leads to depletion of mussel beds, opening of unoccupied space, patchiness in assemblages, and dominance of macroalgae (Airoldi et al. 2005b).

Even when mussel species can be thought to be resistant to local extinction, the ecological function of mussel aggregations can be lost or reduced if overexploited or affected by habitat deterioration. In South America, mollusc extraction is increasing (Fig. 1), and this pressure adds to the chronic impact of historical exploitation of these shellfish (e.g., Jerardino et al. 1992), which has already caused dramatic changes in some coastal ecosystems (e.g., Defeo 2003). Furthermore, several mussel species are exploited, either for subsistence or for artisanal or industrial fisheries (Nishida et al. 2006; Narvarte et al. 2007). Among the wide diversity of shellfish species harvested in South America, extraction of mussel beds may have harmful consequences for the rest of the community, because they provide habitat and recruitment sites for many other species (Fernández et al. 2000). Mussel beds are not as charismatic as other marine ecosystems (e.g., coral
Fig. 1 Trends in South American mollusc production (1990-2004). Gross annual mollusc production (excluding Cephalopods) extracted from FAO statistics is shown discriminated by country

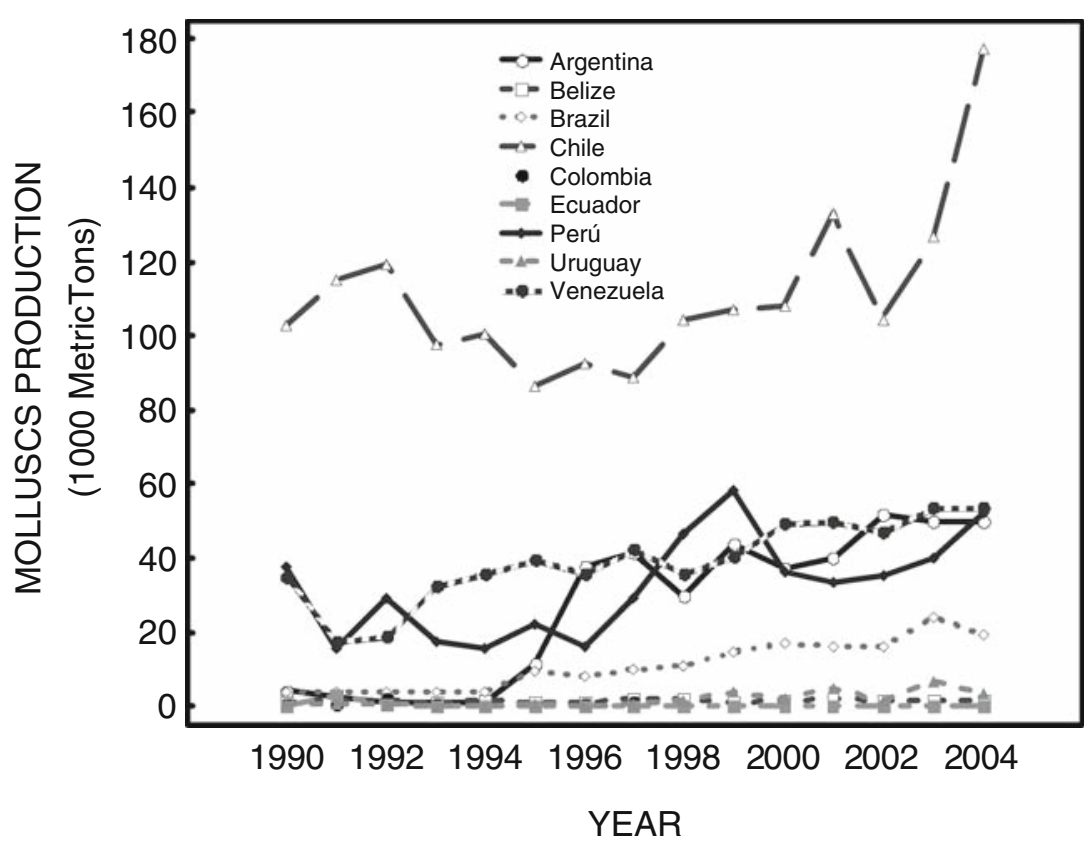


reefs, seagrass beds, mangrove forests and oyster reefs) and, despite their ecological importance, they have not received enough attention because are considered of less economic value than other fisheries resources. Consequently, much less research effort has been done to analyze their management and conservation status.

This paper aims to identify mytilid bioengineering species (i.e., those able to form mats, beds, or any type of aggregation that significantly increases spatial heterogeneity at local scales) that might disproportionately affect local ecosystem functioning. Further, we aim to provide an ecorregional diagnosis of the condition, threats and current management schemes for South American mussels. To this end, we gather information on how mussel resources are being used and their current levels of exploitation. We also address the temporal extractive phases (sensu Castilla and Defeo 2001), experienced by exploited South American mytilid stocks, and the corresponding socio-economic and managerial scenarios. Finally, we review the management schemes implemented and discuss future challenges directed to improve the conservation status of South American mussel populations. Our analysis is entirely focused on wild populations. However, some aquaculture issues are discussed in order to provide a more comprehensive picture of the socio-economic context.

\section{Data gathering}

A comprehensive bibliographic survey was performed in order to identify: (a) habitat-forming mussel species; (b) the biogeographic regions where these species are ecologically important; (c) which species are currently exploited and/or presents conservation issues, particularly exploring the evidence for population declines; (d) the management schemes implemented. We focused primarily on those species that occur in large densities forming beds or reefs, and which may have substantial effects on ecosystem processes. Our search was not restricted to the primary literature, because much of the valuable information is in technical reports, congress abstracts or other grey literature. Though 100 of original sources were surveyed, completeness of this list is not claimed, yet we believe that this review provides a representative overview of the situation for mussels in the region.
The analysis was performed by biogeographic region, following the classification provided by Sullivan and Bustamante (1999) for the study area (Fig. 2): Cold-Temperate South America (CTSA); Warm-temperate Southwestern Atlantic (WTSA); Tropical Southwestern Atlantic Region (TSA); Tropical Northwestern Atlantic Region (TNA); Tropical Eastern Pacific (TEP); and Warm-Temperate Southwestern Pacific (WTSP).

\section{Results}

Cold-Temperate South America (CTSA)

\section{Ecology}

The CTSA region comprises the southern tip of South America, including both the Pacific and Atlantic coast. Southern Chile has a rich diversity of mytilids: Perumytilus purpuratus, Semimytilus algosus, M. edulis, Mytilus chilensis, Choromytilus chorus, Brachidontes granulata and Aulacomya atra are important habitat-forming species inhabiting the region (Table 1). In areas protected from human harvesting, C. chorus, S. algosus and P. purpuratus frequently dominate the mid to lower rocky intertidal (Moreno et al. 1986). Both S. algosus and $P$. purpuratus are capable of forming beds by recruiting directly to the rocky substratum, while recruitment of $C$. chorus depends on a robust filamentous alga, Gymnogongrus furcellatus (Davis and Moreno 1995). In Chile, P. purpuratus forms dense three-dimensional, monospecific matrices (Alvarado and Castilla 1996) using primary substrate (rock) and out-competing sessile barnacles, algae, and other mussels (Castilla and Duran 1985; Alvarado and Castilla 1996; Prado and Castilla 2006). The Chilean mussel "chorito" M. chilensis thrives in the Chilean coast from $\sim 39^{\circ}$ to $44^{\circ} \mathrm{S}$. The sub Antarctic ribbed mussel (A. atra) forms extensive beds in the mid intertidal and infralittoral, even in sedimentary substrates (Pastor de Ward 2000). M. edulis forms important beds along the region, with their main banks located in both intertidal and subtidal areas. In North Patagonian Gulfs (CTSA), beds of A. atra and M. edulis are related to very diverse communities (Zaixso 1999; Zaixso 2004). 
Fig. 2 Summary of ecorregional management and conservation issues for South American mussels

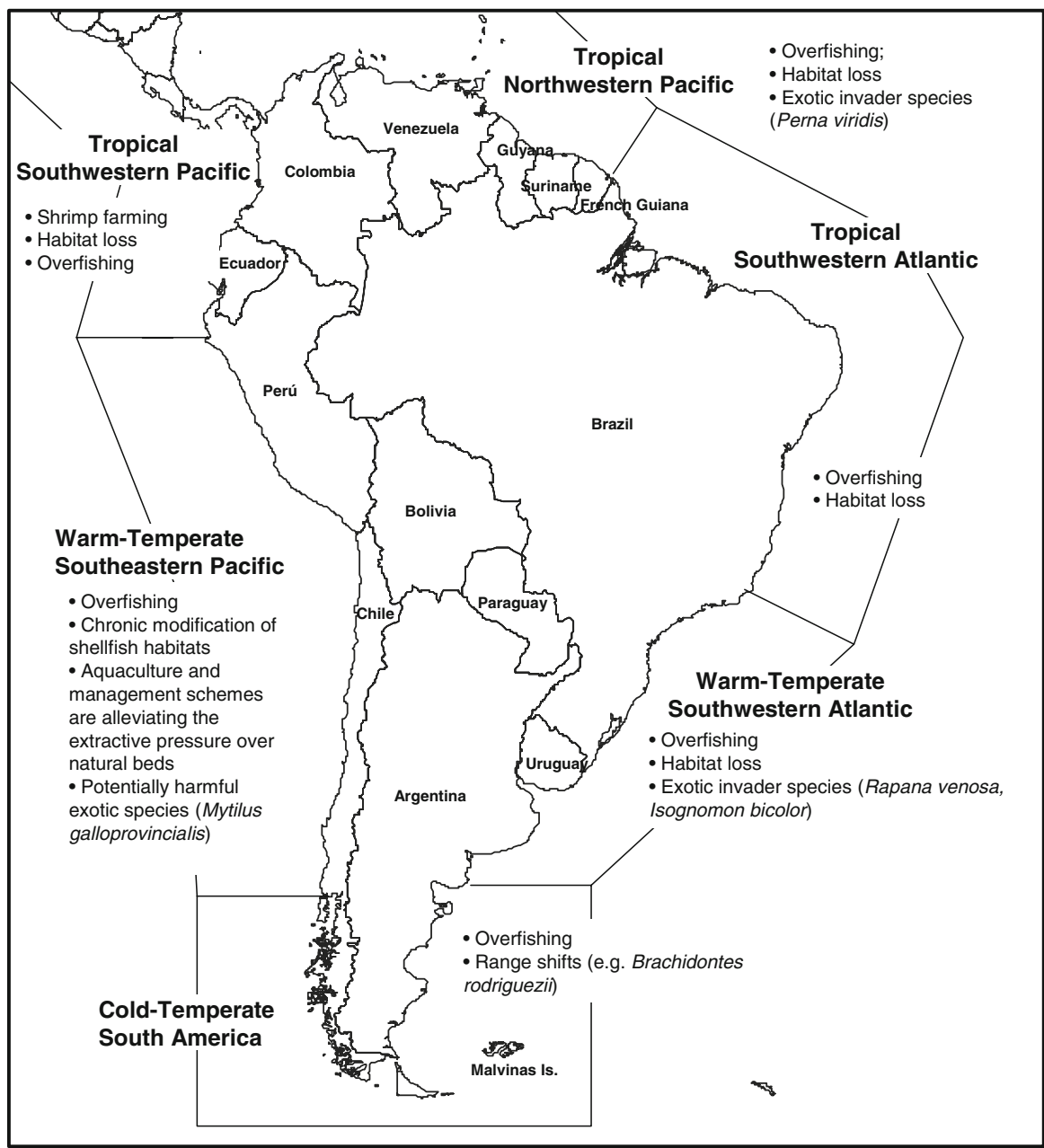

Pacific coast fisheries

Four species: M. edulis, M. chilensis, C. chorus and A. atra, are currently cultured or harvested. The intense exploitation of mussels along the Chilean coast began with the pre-hispanic settlers and increased between the 1950s and the 1960s (see Moreno 1995 and references therein). Nowadays, mussel production in Chile is chiefly made up of M. chilensis, which represents $98 \%$ of farmed mussel production; the rest is made up of A. atra and C. chorus.

\section{Atlantic coast fisheries}

In Argentina, A. atra and M. edulis are exploited by small-scale artisanal fisheries in San Matías Gulf, with approximately 200 or more fishers involved, including intertidal food gatherers, professional "Hookah" divers and artisanal dredging through small boats. These fisheries account for more than 500 Tons/year, with M. edulis harvests of approximately 480 Tons/year since at least 1964 (Narvarte et al. 2007). These authors reported a threefold increase in vessels from 2000 to 2003, while claims for entrance of new vessels increased nearly fourfold over the same period following the discovery of new beds.

\section{Management and conservation issues}

The Pacific rocky intertidal has been increasingly exploited for food by gatherers for at least 8500 years BP (Moreno 2001). Consequently, there have been signs of overexploitation of some mussel species, as 


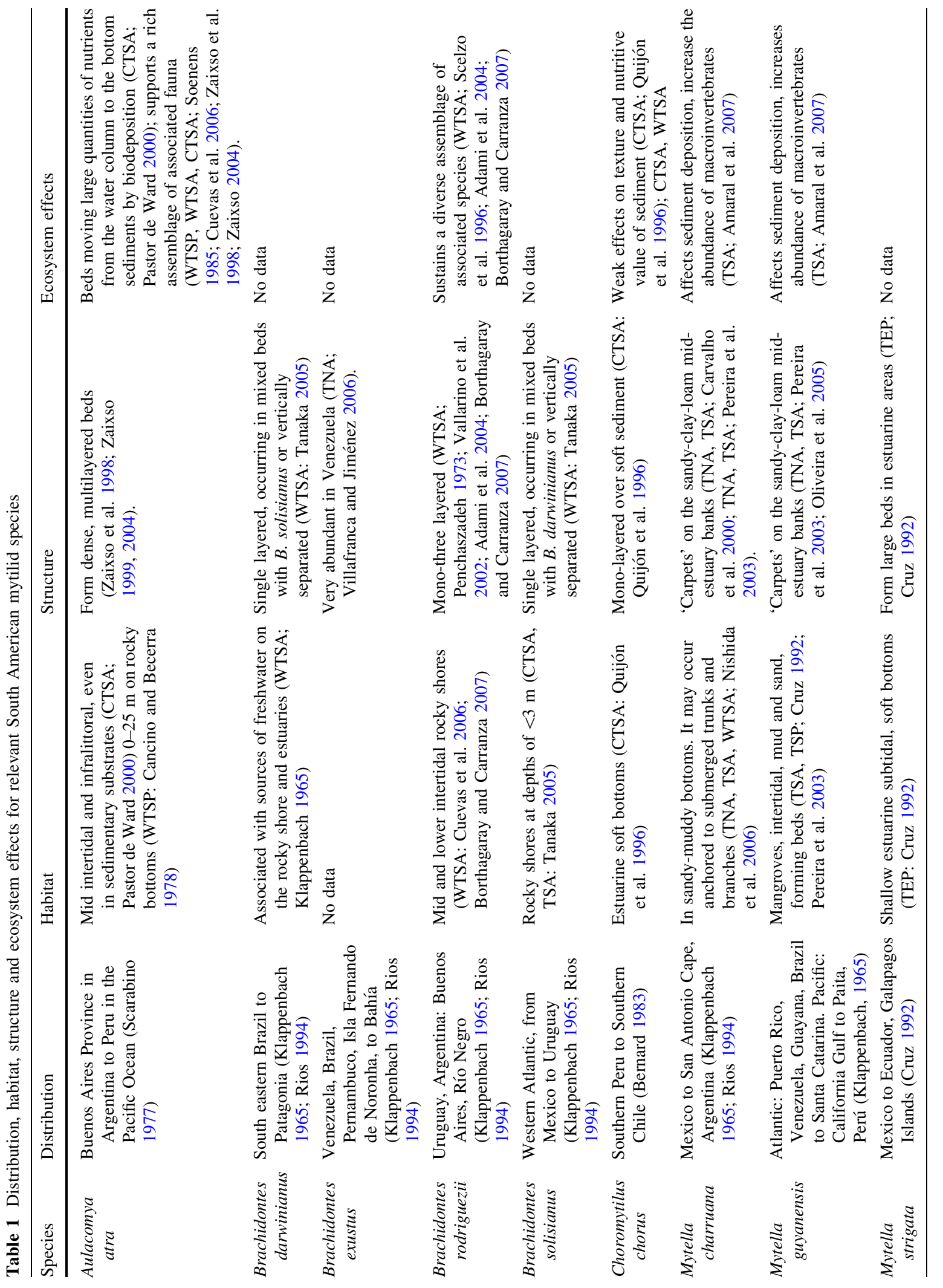




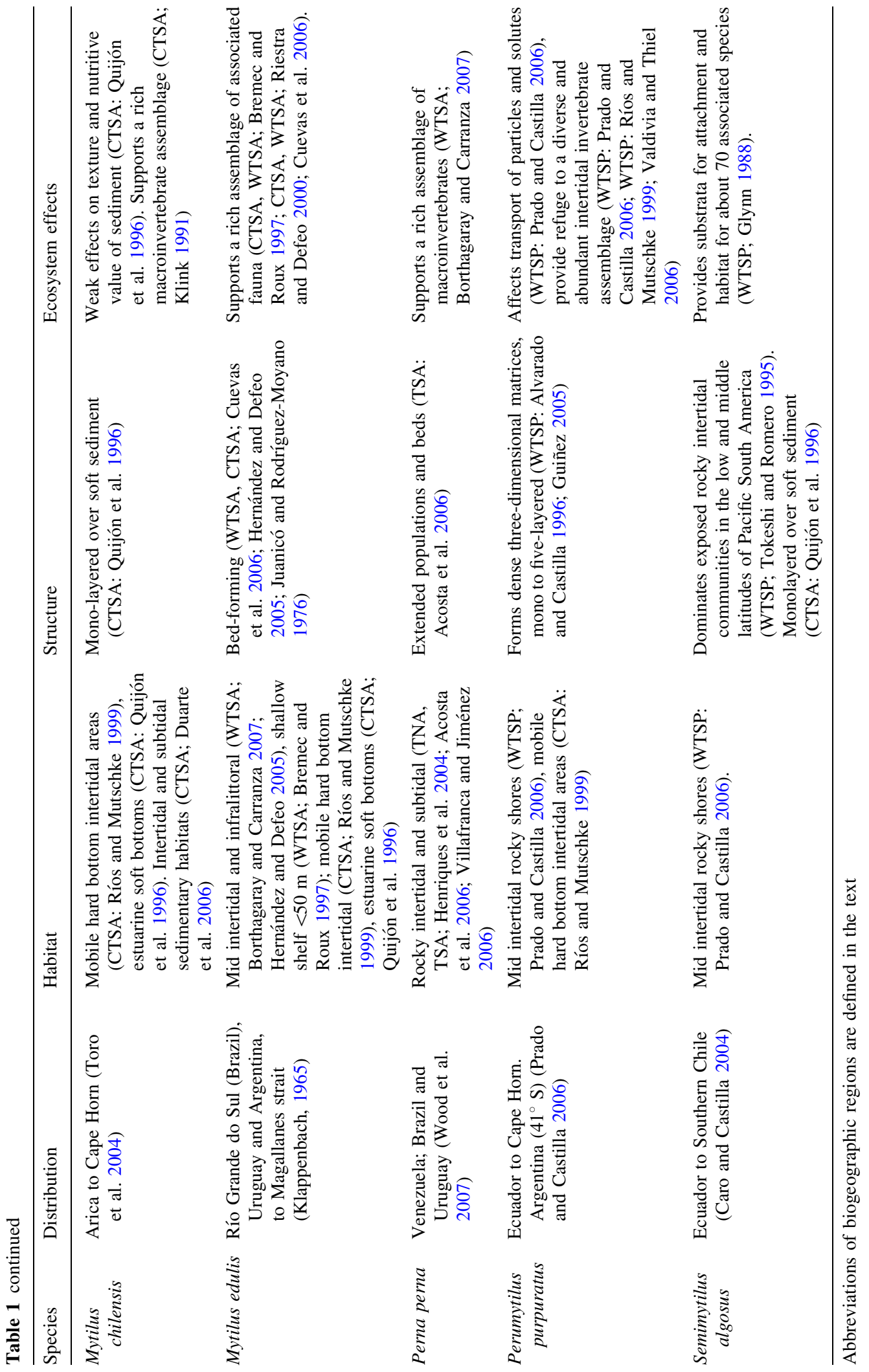


Table 2 Summary of population trends, exploitation modalities and legal framework/regulations for key mussel species in South America

\begin{tabular}{|c|c|c|c|}
\hline Species & Population trends & Exploitation & Regulations \\
\hline $\begin{array}{l}\text { Aulacomya } \\
\quad \text { atra }\end{array}$ & $\begin{array}{l}\text { Decline of natural banks (WTSP; Ancieta } \\
\text { et al. 1979). Decimation of Peruvian } \\
\text { populations during severe ENSO (WTSP; } \\
\text { Glynn 1988). Decline in Patagonian } \\
\text { populations (competition with } \\
\text { B. rodriguezii) (CTSA; Cuevas et al. } \\
\text { 2006) }\end{array}$ & $\begin{array}{l}\text { Commercial harvest in San Matías } \\
\text { Gulf (Argentina). Cultured and } \\
\text { harvested in Chile and Peru. }\end{array}$ & $\begin{array}{l}\text { Renewable permit, } \sim 20 \text { vessels } \\
\text { (Argentina). Legal size, } \\
\text { MEABRs and INTQs (Chile) }\end{array}$ \\
\hline $\begin{array}{l}\text { Brachidontes } \\
\text { rodriguezii }\end{array}$ & $\begin{array}{l}\text { Expanding into the South (CTSA; Cuevas } \\
\text { et al. 2006) }\end{array}$ & $\begin{array}{l}\text { Artisanal hand-gathering (Uruguay, } \\
\text { Argentina) }\end{array}$ & $\begin{array}{l}\text { Open access (Uruguay, } \\
\text { Argentina) }\end{array}$ \\
\hline $\begin{array}{l}\text { Choromytilus } \\
\text { chorus }\end{array}$ & $\begin{array}{l}\text { Intensive exploitation has brought exploited } \\
\text { populations down to very low levels } \\
\text { (WTSP, CTSA; Winter et al. 1984) }\end{array}$ & $\begin{array}{l}\text { Commercial harvest and culture in } \\
\text { Chile }\end{array}$ & $\begin{array}{l}\text { Genetic reserves, legal sizes, } \\
\text { MEABRs and INTQs (Chile) }\end{array}$ \\
\hline $\begin{array}{l}\text { Mytella } \\
\text { charruana }\end{array}$ & $\begin{array}{l}\text { Great reductions in size and geographic } \\
\text { distribution in recent decades (TSA: } \\
\text { Marques-Silva et al. 2006) }\end{array}$ & $\begin{array}{l}\text { Artisanal hand-gathering } \\
\text { (mariscagem) in Brazil }\end{array}$ & $\begin{array}{l}\text { Open access in general; RESEX } \\
\text { in few localities (Brazil) }\end{array}$ \\
\hline $\begin{array}{l}\text { Mytella } \\
\quad \text { guyanensis }\end{array}$ & $\begin{array}{l}\text { Alteration to mangrove ecosystem; shrimp } \\
\text { farming, population decline (TEP; } \\
\text { Ocampo-Thomason 2006) }\end{array}$ & $\begin{array}{l}\text { Artisanal hand-gathering } \\
\text { (mariscagem) in Brazil. }\end{array}$ & $\begin{array}{l}\text { Open access in general; RESEX } \\
\text { in few localities (Brazil) }\end{array}$ \\
\hline $\begin{array}{l}\text { Mytella } \\
\text { strigata }\end{array}$ & $\begin{array}{l}\text { Population decline in urbanized areas and } \\
\text { competition with Mytilopsis trawtiniana } \\
\text { (TEP, Cruz 1992) }\end{array}$ & $\begin{array}{l}\text { Artisanal hand-gathering in } \\
\text { Colombia and Ecuador }\end{array}$ & $\begin{array}{l}\text { Open access (Colombia and } \\
\text { Ecuador) }\end{array}$ \\
\hline $\begin{array}{l}\text { Mytilus } \\
\quad \text { chilensis }\end{array}$ & $\begin{array}{l}\text { Strong declines of populations within the } \\
\text { northern range due to overfishing } \\
\text { (WTSP: Sanchez 2002) }\end{array}$ & $\begin{array}{l}\text { Artisanal harvesting and culture in } \\
\text { Chile }\end{array}$ & $\begin{array}{l}\text { Genetic reserves, legal sizes, } \\
\text { MEABRs and INTQs (Chile) }\end{array}$ \\
\hline Mytilus edulis & $\begin{array}{l}\text { Uruguayan populations threatened by the } \\
\text { invading snail Rapana venosa (WTSA; } \\
\text { this paper). Decline in Patagonian } \\
\text { populations (competition with } B \text {. } \\
\text { rodriguezii) (CTSA; Cuevas et al. 2006) }\end{array}$ & $\begin{array}{l}\text { Diving and dredging in San Matías } \\
\text { Gulf (Argentina) and by diving in } \\
\text { Uruguay }\end{array}$ & $\begin{array}{l}\text { Renewable permit, } \sim 29 \\
\text { vessels; legal size } \\
\text { (Argentina). }\end{array}$ \\
\hline Perna perna & $\begin{array}{l}\text { Overexploitation of natural banks (WTSA: } \\
\text { Henriques et al. 2004). Threatened by the } \\
\text { invasive bivalve Isognomon bicolor } \\
\text { (TSA; Domaneschi and Martins 2002) }\end{array}$ & $\begin{array}{l}\text { Artisanal hand-gathering and } \\
\text { cultured in Venezuela. Farmed } \\
\text { and artisanal hand-gathering in } \\
\text { southern Brazil }\end{array}$ & $\begin{array}{l}\text { Permit required for exploitation } \\
\text { (Venezuela). Extraction from } \\
\text { natural banks prohibited } \\
\text { (Brazil) }\end{array}$ \\
\hline $\begin{array}{l}\text { Semimytilus } \\
\text { algous }\end{array}$ & $\begin{array}{l}\text { Catastrophic losses in intertidal banks } \\
\text { (WTSP; Arntz et al. 1985) }\end{array}$ & No data & No data \\
\hline
\end{tabular}

See text for abbreviations of biogeographic regions and management regulations

in the case of A. atra in Peru (Fig. 3). However, the explosive growth of mussel culture industry, together with the management schemes implemented, are alleviating the extractive pressure over natural beds (see Fig. 4).

In the Pacific coast, fishing pressure from 1938 to 1960 nearly led to the extinction of $C$. chorus and to the collapse of natural banks of M. chilensis and A. atra in Southern Chile (Avila et al. 1994). This spurred the development of aquaculture, as well as attempts to improve natural populations through restoration of natural banks, creation of Marine Reserves and design of specific laws to manage these species (Avila et al. 1994 and Table 2). All exploited species have now a minimum legal size $(5 \mathrm{~cm}$ shell length for $M$. chilensis, $5.5-7 \mathrm{~cm}$ for A. atra, depending on the regions, and $10.5 \mathrm{~cm}$ for $C$. chorus since 1986). In addition, in 1981 the Fishery Subsecretary of Chile created a Genetic Reserve (Reserva Genética Putemun, Estero Castro, DS 248/81) in southern Chile to protect the stocks of C. chorus and M. chilensis and to serve as seed producer. However, yields drastically declined from 20,300 Tons/year in 1993 (only 20\% coming from cultures and the rest from extraction from wild banks) to 2,060 Tons in 2005 (www.sernapesca.cl). This 


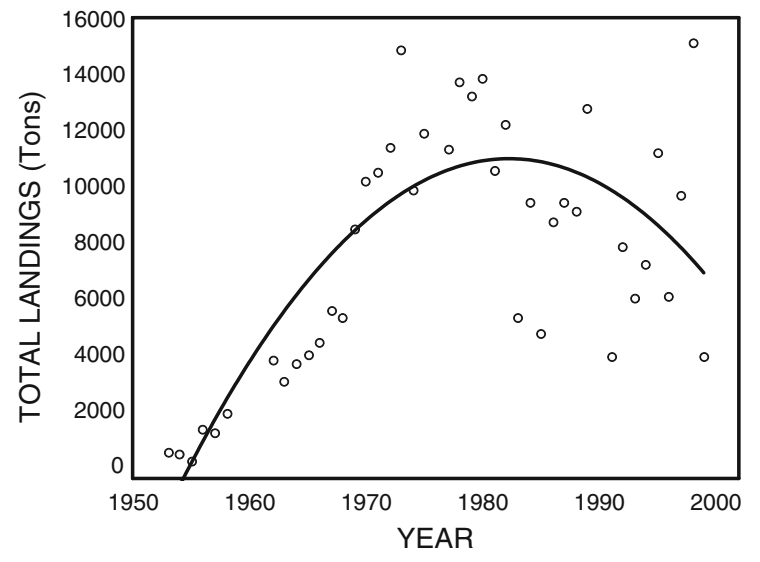

Fig. 3 Trends in Peruvian gross landings (1952-2000) for cholga (Aulacomya atra). A fitted second-order polynomial function is shown $\left(R^{2}=0.56\right)$. Official data from Instituto del Mar del Perú

trend observed in Chilean landings, and for M. chilensis in particular, is most likely due to a shift to aquaculture production and does not necessarily reflect a population decline (Fig. 4).

The largest species, C. chorus, only re-established in some areas protected from shellfish harvesters (Moreno 1995). Similarly, most M. chilensis populations within the northern range of the species distribution have suffered strong declines due to overfishing (Sanchez 2002). This led to restocking practices with mussels extracted from other local populations, usually from Yaldad, which was the most important source of natural 'seed' (juveniles) for aquaculture activities (Winter et al. 1984). Toro et al. (2004) suggested that this humanmediated dispersal may have affected the levels of genetic variation in several northern stocks. In addition, the exotic mussel Mytilus galloprovincialis has also been reported in Southern Chile, but it seems to be confined to mussel aquaculture facilities, and there are no naturally established populations in the wild (Castilla et al. 2005; Castilla and Neill 2009).

In the Atlantic, the few studies available described dramatic changes in the structure and spatial distribution of mussel beds. In Punta Pardelas (Golfo Nuevo, Península Valdés, Argentina), the middle and lower levels are dominated by the small mussel Brachidontes rodriguezii, forming a well-defined belt structure. This species was absent in the $60 \mathrm{~s}$, when

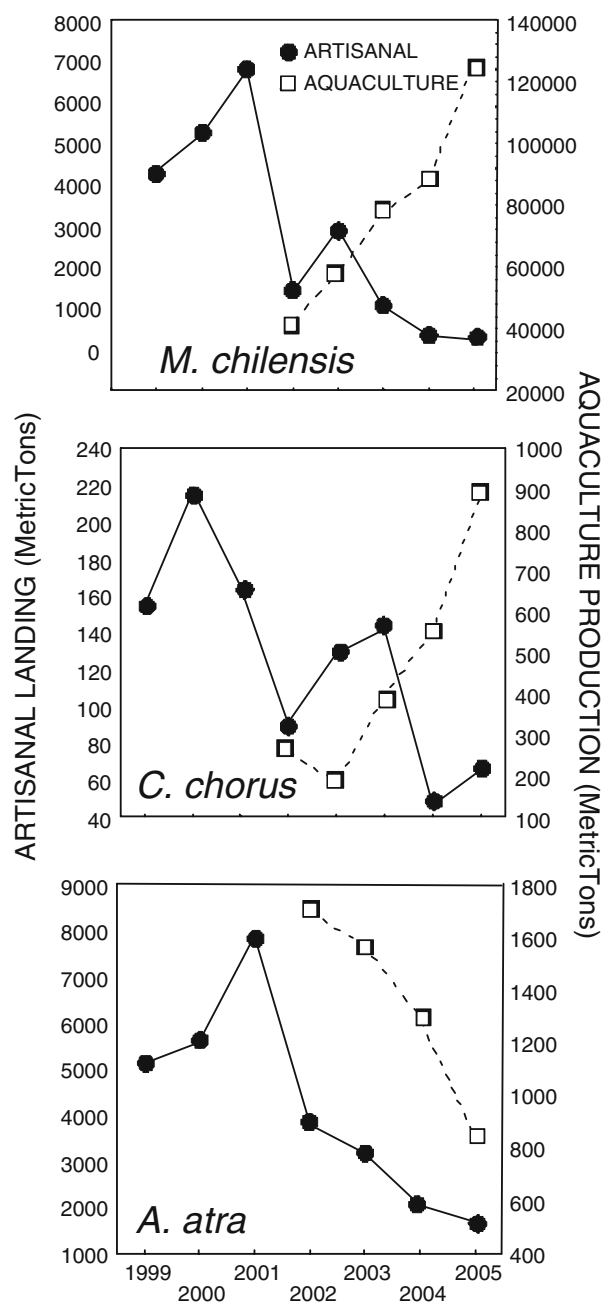

Fig. 4 Trends in Chilean artisanal landings and aquaculture production (1999-2005) for cholga (Aulacomya atra), choro (Choromytilus chorus) and chorito (Mytilus chilensis). Notice that with the exception of $A$. atra, artisanal landings are generally a small fraction of mussel Chilean production. Official data from Servicio Nacional de Pesca (Chile)

the southern mussel $P$. purpuratus was the dominant species and now is of secondary importance in the midlittoral zone (i.e., $<15 \%$ relative abundance). In contrast, the commercial mytilids $M$. edulis and $A$. atra, which dominated the lower midlittoral forming important mussel banks in the 1960s, are now only found in the infralittoral zone (Cuevas et al. 2006). Morsan (2003) reported that the minimum legal size established for mussel harvest has not always been followed, resulting in a large portion of undersized mussels being taken. 
Warm-Temperate Southwestern Atlantic (WTSA)

\section{Ecology}

The main species occurring in this region (Table 1) are the estuarine Mytella charruana and Mytella guyanensis, Brachidontes solisianus, Brachidontes darwininanus and the marine mussels B. rodriguezii, Perna perna and M. edulis. M. charruana (sururú in Brazil) is distributed from the intertidal to the shallow subtidal, while M. guyanensis (sururú or bacucú) can be found in estuarine mangroves (Pereira et al. 2003; Nishida et al. 2006). Both species mainly inhabit mud and sand, forming beds and stabilizing the sediment. In contrast, beds of $B$. rodriguezii, $P$. perna and M. edulis can be also found over hard substrata and are of ecological importance only in southern Brazil, Uruguay and Argentina, while all the remaining species are also distributed along the Brazilian coast. B. darwinianus occurs in rocky shores from SE Brazil to the north of Patagonia, and is generally associated with sources of freshwater and estuarine environments (Klappenbach 1965; Rios 1994; Scarabino et al. 2006). In Brazil, this species overlaps with B. solisianus, usually forming a single layer in intertidal habitats, occurring in mixed beds or vertically separated (Tanaka and Magalhães 2002; Tanaka 2005).

\section{Fisheries}

The brown mussel $P$. perna is the most important species in Southern Brazil, both in terms of landings and economic value (da Costa and Nalesso 2006). This species is also collected by small scale artisanal hand gatherers in the rocky intertidal of the Uruguayan coast (Scarabino et al. 2006; Carranza and Borthagaray 2008). The estuarine mussel M. charruana is exploited in the Brazilian coast, mainly for local consumption (Pereira et al. 2003). In Uruguay, during the 1970s, beds of M. edulis in the inner shelf (50 $\mathrm{m}$ depth) have been commercially extracted (Juanicó and Rodríguez-Moyano 1976). This fishery is fully exploited (i.e., increase in fishing effort and catches are not permitted), being extracted by divers in Isla de Lobos and Gorriti islands (Riestra and Defeo 2000; Hernández and Defeo 2005). Recreational harvest of the sympatric Brachidontes species (B. rodriguezii and B. darwinianus) occurs along the coast of Uruguay (Scarabino et al. 2006).
Management and conservation issues

In subtropical areas of Brazil, the uncontrolled exploitation of natural beds of Mytella spp. has raised concerns about the sustainability of these fisheries (Table 2). There is evidence of great reductions in individual size and geographic distribution for M. charruana in recent decades (MarquesSilva et al. 2006). Oliveira et al. (2005) estimated an effective population size of 300,000 individuals for M. guyanensis, and 540,000 individuals for M. charruana. These figures are much smaller than the estimated actual population sizes, suggesting population unstability (Oliveira et al. 2005). In addition, this high population variability, associated with high mortality rates after uncommonly rainy seasons, has increased the likelihood of local extinctions (Oliveira and Kjerfve 1993).

There are at least two cases in which exotic invader species directly threaten some mussel species in the region (Table 2): in Uruguay, the alien gastropod Rapana venosa, introduced in the Rio de la Plata in the 1990s (Scarabino et al. 1999), now occurs in high densities in areas where the commercial banks of M. edulis are located (G. Martinez pers. comm.), and thus a strong negative impact on mussel beds is expected in the short term. The invading Caribbean bivalve Isognomon bicolor introduced in Brazil during the 1980s (Domaneschi and Martins 2002), is another threat for mussel species in Southern Brazil. This species is now distributed in consolidated substrata from Rio Grande do Norte to Santa Catarina (Brazil). Its abundance has increased, and competition for space with the native malacofauna is probably taking place. Some observations documented the replacement of the formerly dominant species such as $B$. solisianus and $P$. perna (Ferreira-Silva et al. 2007). In Uruguay, the lack of monitoring and management plans for commercially exploited mytilids has increased overexploitation risks (Scarabino et al. 2006).

Tropical Southwestern Atlantic region (TSA)

\section{Ecology}

There are only two rocky outcrops in northeastern Brazil, because the area is dominated by mangrove ecosystems. In these rocky shores, B. solisianus and 
B. exustus often form important intertidal beds (Castro and Alves 2007). In mangrove ecosystems, the estuarine mussels Mytella spp. have high ecological importance, because they live buried in the surface of the mangrove mud, forming beds. In the region, $M$. charruana is a quite abundant mytilid that forms 'carpets' on the sandy-clay-loam mid-estuary banks, or may occur anchored to submerged trunks and branches (Nishida et al. 2006). These beds sustain a rich macroinvertebrate assemblage and affect several ecosystem processes, including patterns of sediment deposition (Amaral et al. 2007).

\section{Fisheries}

The early use of molluscs by human populations in Brazil (mariscagem) is evidenced by the existence of sambaquis, prehistoric deposits of shells, that occurs in the Brazilian coast near many towns close to estuaries (Nishida et al. 2006). M. charruana and M. guyanensis are collected in Northeastern Brazil by artisanal hand gatherers using a wide variety of techniques (Nishida et al. 2006). In some places, gatherers use a straight-bladed sickle to remove mussel anchored to submerged trunks and branches of trees. This activity is of high socio-economic interest for local people: Grasso (2000) assigned market prices to mangrove subsistence production and found high subsistence values for mussel products. Some of these mangrove-dependent subsistence incomes even surpass the monthly cash income of rural producer households.

\section{Management and conservation issues}

There is evidence of a marked decline of mussel stocks along the Northeastern Brazilian coast, which has been ascribed to direct overexploitation and, indirectly, to the loss of mangrove habitat. Overexploitation of natural mussel populations has been suggested as responsible for unusually low settlement levels of M. charruana in the Caeté estuary (Blandtt and Glaser 1999; Glaser 2003). Populations of M. charruana in neighbouring Maranhao State are now being exploited due to the collapse of mussel populations in the Bragança region. Marques-Silva et al. (2006) documented the decimation of two large mussel banks (ca. 500 and $700 \mathrm{~m}$ each one) caused by intense extraction. Mussels no longer occur in these places, which are mainly covered now by coarse sediments (Marques-Silva et al. 2006). The local extinction of sururú has also been linked to stock depletion of several estuarine fish that prey upon Mytella spp. (Fukuda et al. 2007).

In Northern Brazil, although federal laws ban all kind of human interference, with the exception of scientific, educational and ecosystem recovery work in mangroves, illegal extractive activities are currently threatening these fragile ecosystems, making the discrepancy between legislation objectives and reality evident (Saint-Paul 2006). Mangrove fisheries often support lower rural income groups, and in some places mussel gathering is one of the most important activities (Saint-Paul 2006). In the context of widespread rural poverty in coastal Northern Brazil, mangrove management should take into account subsistence production, which has a central socioeconomic function (Glaser 2003).

Traditionally, management of mytilid fisheries in Brazil has followed a top-down approach (i.e., government dictate regulations). Recently, a Brazilian model of co-management for natural resources, known as "reservas extrativistas" (RESEX: Table 2), was developed with fishers and government agencies as partners (Glaser and da Silva Oliveira 2004). However, the new rights for local users allocated under the RESEX co-management concept are contrary to existing environmental legislation, generating a still unresolved conflict (Glaser and da Silva Oliveira 2004).

\section{Tropical Northwestern Atlantic region (TNA)}

\section{Ecology}

Information for this region is manly restricted to Venezuela and Caribbean Colombia, and it is almost nonexistent for Guyana and Belize. Brachidontes modiolus, B. exustus and $P$. perna are the native mussels commonly found in the rocky intertidal (Fernández et al. 2007). The main ecosystem-engineering species is P. perna, which forms extensive intertidal beds along the north shore of Venezuela (Acosta et al. 2006), while Brachidontes and Modiolus species are of lesser importance. However, the subtidal Modiolous squamosus is very abundant in sandy and muddy bottoms associated with Thalassia testudinum (Prieto et al. 1999b). 


\section{Fisheries}

Perna perna is found in large natural banks along Venezuela, being intensively exploited and cultured by artisanal and industrial fisheries (Acosta et al. 2006). Some local small industries also harvest and process mussels and pearl oysters (Mckenzie et al. 2003), but there is limited information on catches.

\section{Management and conservation issues}

Non-native species probably present the biggest issue in the region, although the artisanal mussel fishery could be partially responsible for the decline of P. perna (C. Lodeiros pers. com). The non-native green mussel Perna viridis was reported in the Gulf of Paria (Venezuela) in 1993, causing large impacts in coastal benthic ecosystems, including the replacement of the native $P$. perna. In 1999-2000, $P$. viridis dominated and displaced the native mussels $P$. perna, B. exustus, Musculus lateralis, Modiolus americanus and M. squamosus in some areas (Prieto et al. 1999a). This invasion is of particular concern, since non-native sibling species may obscure the regional decline of some native mussel species (e.g., M. trossulus and M. galloprovincialis in California, see Geller 1999).

Mussel beds in Península de Paria have found to be promissory for sustaining artisanal or subsistence fisheries (Prieto et al. 2007), even though these systems are particularly vulnerable to anthropogenic disturbances (Prieto et al. 2007). Although there are fishery regulations on oysters (Crassostrea rhizophorae) and on the "pepitona" Arca occidentalis in Venezuela, these are not enforced properly, thus leading to overexploitation of some local stocks (MARN 2000).

Tropical Eastern Pacific (TEP)

\section{Ecology}

The TEP region has two estuarine mussel species: Mytella strigata and M. guyanensis, of ecological and socio-economic importance (Cruz 1992). The former mainly occurs in shallow estuarine subtidal environments, while the latter is more common in intertidal soft sediment habitats and associated with mangroves (Table 1). Both species form clumps or aggregations (Cruz 1992).

\section{Fisheries}

Traditional mangrove resource exploitation in the region includes hand gathering of the two associated mussel Mytella species, which are mainly collected by women and children in estuarine environments of the Colombian Pacific (FAO 1994) and Ecuador (ECOLAP-MAE 2007). In some mangrove ecosystems of Ecuador, as the Ecological Mangrove Reserve Cayapas-Mataje, fishing (including mollusc gathering) is one of the most important economic activities, with $85 \%$ of the households depending on them (Ocampo-Thomason 2006).

\section{Management and conservation issues}

Mangrove ecosystems in the region are severely threatened by shrimp farms, which have led to severe mussel declines (Table 2). In Cayapas-Mataje reserve (Ecuador), the development of shrimp farming (approximately 3,000 ha) led to the destruction of cockle-gathering grounds (Ocampo-Thomason 2006) and the decline of mussel populations. In some areas, fishers are currently developing small programs to restore mussel populations that have been reduced by $80 \%$ in the last 15 years (Dudenhoefer 2002). Localized stock depletion has also been reported in populations of M. strigata in the Gulf of Guayaquil (Ecuador), possibly exacerbated by negative interactions with Mytilopsis trawtiana (Cruz 1992).

The growing concerns about the impacts of shrimp farming in Ecuador have led to the creation of a new stewardship areas called 'custodias', where mangrove areas are allocated to local communities for their traditional use and management, and other commercial practices such as charcoal production, logging or shrimp farming. The custodial permit is given by the Minister of Environment to local gatherers only and has duration of 10 years. After this period, the 'custodia' will be inspected by the Ministry, and an extension of 90 years will be granted if it is demonstrated that the community has appropriately looked after it (Ocampo-Thomason 2006). 
Warm-Temperate Southwestern Pacific (WTSP)

\section{Ecology}

The WTSP region shares most of the species with CTSA. In addition, three species of Brachidontes (Brachidontes playasensis, Brachidontes puntarenensis, and Brachidontes semilaevis) and three species of Mytella (Mytella arciformis, M. guyanensis and M. speciosa) occur in the Peruvian coast (Sala et al. 2002). In central and Southern Chile, south of $33^{\circ} \mathrm{S}$, mussel beds of $P$. purpuratus cover more than $80 \%$ of the substratum in the mid intertidal zone (Castilla 1981; Paine et al. 1985). North of $32^{\circ} \mathrm{S}$ mussel beds are scarce, but appear again as dominant components of the mid intertidal zone north of $20^{\circ} \mathrm{S}$ and up to subtropical areas in Peru. These mussels have overriding importance as ecosystem engineers (Table 1) and provide microhabitats for a large number of small, mussel habitat-dependent species, as well as for other species that depends on the mussel beds either for refuge or recruitment (Fernández et al. 2000). In Peru, nearly 100 species have been reported associated with beds of the ribbed mussel A. atra (Soenens 1985).

\section{Fisheries}

Fisheries issues identified for the CTSA also applies for the WTSP. In the Peruvian coast, the fishery for the ribbed mussel A. atra is the most important mytilid fishery, comprising nearly half of the artisanal shellfish landings. The species is extracted by hookah divers operating between 5 and $25 \mathrm{~m}$ depth (PADESPA 2003). In addition, mangrove-associated species (e.g., M. guyanensis) play an important role in local economies and constitute an important food source for local Peruvian populations (Moran 2004).

\section{Management and conservation issues}

Most of the concepts expressed for the Pacific coast in the CTSA region can also apply to the WTSP. Longterm human exclusion experiments conducted in Central Chile showed that harvested areas of the middle intertidal rocky shore formerly dominated by a monoculture of mussels, $P$. purpuratus, switched to barnacle dominance in the absence of fishing (Castilla 1999). These dramatic changes were mediated by the muricid gastropod Concholepas concholepas, an intensively harvested keystone predator. Exploitation of this muricid led to mussel monocultures, which may affect local diversity via monopolization of available space. Conversely, the diversity of benthic primary substratum users notably increased in protected areas when compared with areas open to harvesting (Castilla and Duran 1985; Castilla 1999). Experimental evidence also suggests that beds of $P$. purpuratus may be particularly sensitive to disturbances, partially as a result of the inability of mussel larvae to settle directly onto bare rock, particularly in the absence of recruitment mediators (Navarrete and Castilla 1993). In addition, the northernmost populations of the ribbed mussel A. atra are particularly vulnerable to climate shifts (Castilla and Guiñez 2000). In particular, $88 \%$ of A. atra banks observed along the central Peruvian coast entirely disappeared, together with their associated biota, by mid 1983 (Glynn 1988), as a result of the strong ENSO event. This effect, together with the lack of management measures directed to control fishing effort, may be partially responsible for the overall fluctuating and declining trends in Peruvian landings (Fig. 3). High extracting pressure that decimated the resource forced fishers to search for new beds in deeper places far away from their ports. Market supply with ribbed mussels derived from aquaculture facilities has not been successful, due to low market prices (PADESPA 2003).

\section{Mussel fisheries management and conservation: prospects}

Three major continental-scale threats affecting mussel populations in South America have been identified: non-sustainable exploitation of mussel beds, habitat loss and invading species. Since the two latter issues are far more complex and elusive goals, vastly treated elsewhere, in this section we focus the discussion on management schemes. Similarly, since marine reserves (no-take areas) only cover less than $0.1 \%$ of the exclusive economic zone of South American and Caribbean countries, and given that there are only four with information published about them in primary scientific journals (PISCO 2008), we restrict our discussion to management schemes likely to be implemented beyond the 
establishment of no take areas. Further, it has been shown for the Mediterranean coast that fully protected areas can be unable to increase mussel populations due to trophic cascade effects, while partial reserves, where fish populations are exploited and mussels protected, are areas where the mussel populations can recover (Rius and Zabala 2008).

Artisanal benthic shellfisheries are a widespread activity in South America (Castilla and Defeo 2001). However, exploitation regimes and management schemes markedly vary between countries, as well as the degree of effective enforcement of the existent regulations (Table 2). Castilla and Defeo (2001) defined five contrasting exploitation phases to describe long-term landings of benthic shellfisheries in South America: (1) initial exploitation; (2) expansive extraction; (3) full exploitation to overexploitation; (4) closures; and (5) stabilization of extraction and institutionalization. In our preliminary analysis, nearly one/third of the fisheries analyzed in this paper showed characteristics that may contribute to the lack of sustainability and their overexploitation, while a half are either in the initial exploitation phase or in the stabilization of extraction and institutionalization phase. Two fisheries: P. perna in Venezuela and Mytella spp. in TEP are still hard to be categorized because of the lack of information. Conversely, there is almost no evidence of unexploited species with conservation problems. However, there may be a bias in the availability of information towards exploited species, leading to two different scenarios: (a) unexploited species do not present conservation problems; or (b) they present conservation issues but are underreported in the scientific literature.

It is difficult to suggest general continental-scale recommendations to improve the sustainable management of South American mussel stocks, because the different fisheries embrace very distinct ecological and socio-economic idiosyncrasies. However, Territorial User Rights for Fishing (TURFs) and comanagement practices are promising tools for linking economic development and poverty alleviation and can enhance the sustainability of the mussel extraction in South America (Defeo and Castilla 2005). To date, the best examples of this management scheme are in Chile, the main mollusc producer in South America (Fig. 1). In this country, local communities self-allocate extraction quotas to fisher members
(Individual Non-Transferable Quotas, INTQ), based on total allowable catches (TAC) regulated by the authority. In addition, there are access rules and selfpolicing strategies among fishers, whereas the government retains the authority to modify management plans by setting or modifying operational management measures such as legal sizes, closures or gear regulations (Castilla and Defeo 2001). In this way, co-management and fisher participatory tools for the extraction of benthic resources were incorporated into the Chilean Fisheries and Aquaculture Law. This law includes the implementation of TURFs and TAC's exclusively assigned to small-scale benthic shellfish artisanal communities through Management and Exploitation Areas for Benthic Resources (MEABRs). However, to date, we lack an assessment on the effects of MEABRs in mussel beds, although there are evidence of positive effects on non-target species inside these areas (Gelcich et al. 2008). In this vein, findings from an analysis of progressive small-scale fisheries worldwide revealed high success in the social organization and regulation of resources among these progressive fisheries but poor evidence for improved ecosystems (McClanahan et al. 2008). More evaluations concerning the ecological impacts of these managerial scenarios on mytilids are needed. These management approaches would not be applicable elsewhere. For example, irregular recruitment patterns characteristic of several mytilids generate "pulses" of exploitation (Navarte et al. 2007). This, coupled with the existence of metapopulations with unknown connectivity patterns and inadequate comprehension of their structure, inhibit the consideration of bivalve stocks as self-sustaining, such as in Argentinean mussel species (Navarte et al. 2007). In this fishery, fluctuating landings has been partially attributed to natural variations in recruitment, and there is no evidence that the fishery has been responsible for resource collapse in the northern zone of the gulf (Narvarte et al. 2007). So, even under a highly enforced management scheme involving TURFs and co-management, resource users may be negatively affected by externalities (e.g., low or null recruitment).

In summary, idiosyncratic physical, biological and/or socio-economical features of mytilid fisheries preclude the existence of a single tool that can ensure the sustainability of mussel fisheries, but right-based approaches are increasingly applied with success, 
notably involving different degrees of co-management together with explicit allocation of TURFs. In South American artisanal fisheries, the implementation of management measures designed for industrial-scale fisheries (reduction of fleet, ground facilities, and subsidies, moratoria on new entrants into the business and administration of catch quotas) are unrealistic. This due to the large social and economic costs for developing countries and because there is not sufficient information about local ecosystem functioning (Castilla and Defeo 2005). Involvement of stakeholders, who must be aware of the need for the conservation of the natural resource as a guarantee for its sustainable exploitation, is a growing concern under the new co-management paradigm (Castilla and Defeo 2005). Mollusc gatherers are critical stakeholders in the process of establishing management plans directed to ensure a sustainable exploitation of stocks in South America (Castilla and Defeo 2001). Finally, the potential for cultivation of commercially important native mussels should be explored in order to develop another avenue of problem solving. Mussel aquaculture is also a part of the solution and can reduce harvest pressure on wild populations. Restoration of natural beds should simultaneously provide an alternative to or be linked with sustainable extraction from wild beds, which, at the same time, should enhance positive ecosystem-level effects (e.g., Brumbaugh et al. 2006). The challenge to revitalizing native mussel beds through restocking experiments is enormous, but it also offers great potential to the restoration of coastal ecosystems and to build commitments among key stakeholders to return their vital functions.

\section{Conclusions}

We identified 14 mussel species/populations (at least nine being currently exploited) that deserve further attention due to their ecological importance. Several local mussel stocks are showing signs of population decline. From a fisheries perspective, nearly one-third of the fisheries analyzed in this paper can be considered as fully exploited or overexploited. In this vein, and given the sedentary/sessile features of mussels, successful management schemes will depend on the incorporation of spatially explicit, local-scale measures. Allocation of TURFs, together with other spatially explicit operational (legal sizes, marine reserves, MPAs) and institutional (co-management) tools, will provide management redundancy (sensu Caddy and Defeo 2003) in regulations directed to improve sustainability in extractive practices. At the same time, this framework will provide an effective means for linking economic development and poverty alleviation for poorly developed South American countries. In addition, aquaculture of native species will serve as an alternative to or be linked with extractive activities, promoting the restoration of depleted beds and associated ecosystem services. The development of experimental management practices involving the active compromise of local communities is strongly suggested as a primary tool for achieving sustainability in South American mussel fisheries. A paradigm shift is needed for managing South American mussel fisheries, helping to ensure their sustainable exploitation and including non-use factors, such as biodiversity and other ecosystem services, which are still poorly evaluated and managed in even the most progressive smallscale fisheries (McClanahan et al. 2008).

Acknowledgments Financial support to A. C. and O. D. by The Nature Conservancy, The Kabcenell Family Foundation and the project UTF/URU/025/URU (Uruguay) is acknowledged. Special thanks to F. Scarabino and L. Prado that provided invaluable bibliography. A. C. acknowledges Marina and Estela for encouragement and support. FONDAP-FONDECYT project $1500-01$ provided additional funds to complete this work.

Open Access This article is distributed under the terms of the Creative Commons Attribution Noncommercial License which permits any noncommercial use, distribution, and reproduction in any medium, provided the original author(s) and source are credited.

\section{References}

Acosta V, Prieto A, Lodeiros C (2006) Índice de condición de los mejillones Perna perna y Perna viridis (Bivalvia: Mytilidae) bajo un sistema suspendido de cultivo en la Ensenada de Turpialito, Golfo de Cariaco, Venezuela. Zootec Trop 24:177-192

Adami ML, Tablado A, López Gappa J (2004) Spatial and temporal variability in intertidal assemblages dominated by the mussel Brachidontes rodriguezii (d'Orbigny, 1846). Hydrobiologia 520:49-59. doi:10.1023/B:HYDR. 0000027724.42811 .19

Airoldi L, Abbiati M et al (2005a) An ecological perspective on the deployment and design of low-crested and other 
hard coastal defence structures. Coast Eng 52:1073-1087. doi:10.1016/j.coastaleng.2005.09.007

Airoldi L, Bacchiocchi F et al (2005b) Impact of recreational harvesting on assemblages in artificial rocky habitats. Mar Ecol Prog Ser 299:55-66. doi:10.3354/meps 299055

Alvarado JL, Castilla JC (1996) Tridimensional matrices of Perumytilus purpuratus on intertidal platforms with varying wave forces in central Chile. Mar Ecol Prog Ser 133:135-141. doi:10.3354/meps 133135

Amaral ACZ, Silva CF, Taffarello CC, Daolio RF, Yokoyama LQ, Abrahão JR, MacCord FS (2007) Fauna associada a bancos lamosos de Mytella charruana (Bivalvia: Mytilidae). Livro de Resumos-XII Congresso Latino-Americano de Ciências do Mar-XII COLACMAR Abstract 40000317

Ancieta F, Vera J, Berger CC, Viacava MC (1979) Diagnostico de la maricultura en Perú. Revista de la Comisión Permanente del Pacífico Sur, $\mathrm{N}^{\circ} 10$

Arntz WE, Landa A, Tarazona J (1985) “El Niño”, su Impacto en la fauna marina. Boletín del Instituto del Mar (Perú) Spec. Vol., 222 pp

Avila M, Lizama MS, Plaza HP, Bustos E, Otaíza R (1994) Estado de situación y perspectivas de la acuicultura en Chile. SGI-IFOP 94(1)

Bayne BL (1976) Marine mussels: their ecology and physiology. Cambridge University Press, Cambridge

Bernard FR (1983) Catalogue of the living Bivalvia of the Eastern Pacific Ocean: Bering Strait to Cape Horn. Can Spec Publ Fish Aquat Sci 61:1-102

Blandtt LS, Glaser M (1999) A escassez do mexilhao (Mytella sp.) no manguezal da bacia do Rio Caete em Bragança. In: $5^{\circ}$ Workshop do Programa MADAM (Mangrove Dynamics and Management) Universidade Federal do Pará, Belém, Brazil, pp 17-18

Borthagaray AI, Carranza A (2007) Mussels as ecosystem engineers: their contribution to species richness in a rocky littoral community. Acta Oecol 31:243-250. doi:10.1016/ j.actao.2006.10.008

Bremec CS, Roux C (1997) Resultados del análisis de una campaña de investigación pesquera, sobre comunidades bentónicas asociadas a bancos de mejillón (Mytilus edulis platensis D’Orb.) en costas de Buenos Aires, Argentina. Rev Inv Des Pesq 11:153-166

Brumbaugh RD, Beck MW, Coen LD, Craig L, Hicks P (2006) A practitioners' guide to the design and monitoring of shellfish restoration projects: an ecosystem services approach. The Nature Conservancy, Arlington, $34 \mathrm{pp}$

Caddy JF, Defeo O (2003) Enhancing or restoring the productivity of natural populations of shellfish and other marine invertebrate resources, FAO Fisheries Technical Paper. No. 448, Rome

Cancino J, Becerra R (1978) Antecedentes sobre la biología y tecnología del cultivo de Aulacomya ater (Molina, 1782) (Mollusca: Mytilidae). Biología Pesquera (Chile) 10: 27-45

Caro AU, Castilla JC (2004) Predator-inducible defences and local intrapopulation variability of the intertidal mussel Semimytilus algosus in Central Chile. Mar Ecol Prog Ser 276:115-123. doi:10.3354/meps276115

Carranza A, Borthagaray AI (2008) The brown mussel Perna perna in the native mussel beds of Cerro Verde (Uruguay). JMBA2-Biodiv Rec: Published on-line
Carvalho GPd, Cavalcante PBS, Castro ACLd, Rojas M-OAI (2000) Preliminary assessment of heavy metals in Mytella falcata (Bivalvia: Mytilidae) from Bacanga river estuary, Sao Luis, State of Maranhao, Notrheastern Brazil. Rev Bras Biol 60:11-16

Castilla JC (1981) Perspectivas de investigación en estructura y dinámica de comunidades intermareales rocosas de Chile central. II. Depredadores de alto nivel trófico. Medio Ambiente Chil 5:190-215

Castilla JC (1999) Coastal marine communities: trends and perspectives from human-exclusion experiments. Trends Ecol Evol 14:280-283. doi:10.1016/S0169-5347(99) 01602-X

Castilla JC, Defeo O (2001) South American benthic shellfisheries: emphasis on co-management and experimental practices. Rev Fish Biol Fish 11:1-30. doi:10.1023/ A: 1014235924952

Castilla JC, Defeo O (2005) Paradigm shifts needed for world fisheries. Science 309:1324-1325. doi:10.1126/science. $309.739 .1324 \mathrm{c}$

Castilla JC, Duran LR (1985) Human exclusion from the rocky intertidal zone of central Chile: the effects on Concholepas concholepas (Gastropoda). Oikos 45:391-399. doi: $10.2307 / 3565575$

Castilla JC, Guiñez R (2000) Distribuciones geográficas disyuntas de invertebrados bentónicos intermareales y del submareal somero en el Hemisferio. Rev Chil Hist Nat 73:585-603

Castilla JC, Neill PE (2009) Marine bioinvasions in the Southeastern Pacific: status, ecology, economic impacts, conservation and management. In: Rilov G, Crooks JA (eds) Biological invasions of marine ecosystems: patterns, effects, and management. Ecological Studies 204. Springer-Verlag, Heidelberg, pp 439-457

Castilla JC, Uribe M, Bahamonde N, Clarke M, DesqueyrouxFaúndez R, Kong I, Moyano H, Rozbaczylo N, Santelices B, Valdovinos C, Zavala P (2005) Down under the southeastern Pacific: marine non-indigenous species in Chile. Biol Inv 7:213-232. doi:10.1007/s10530-0040198-5

Castro GAD, Alves RSC (2007) Variações espaço-temporal na estrutura de tamanhos de Collisella subrugosa (Orbigny, 1846) (Gastropoda, Acmaeidae) da região entremarés de costões rochosos da baía de Benevente (ES). Livro de Resumos-XII Congresso Latino-Americano de Ciências do Mar-XII COLACMAR: Abstract 4000207

Coleman FC, Williams SL (2002) Overexploiting marine ecosystem engineers: potential consequences for biodiversity. Trends Ecol Evol 17:40-44. doi:10.1016/S01695347(01)02330-8

Costanza R, d'Arge R, de Groot R, Farber S, Grasso M, Hannon B, Limburg K, Naeem S, O’Neill RV, Paruelo J, Raskin RG, Sutton P, van den Belt M (1997) The value of the world's ecosystem services and natural capital. Nature 387:253-260. doi:10.1038/387253a0

Cruz M (1992) Estado actual del recurso malacológico (Bivalvos y Gasterópodos) en la zona infralitoral del Golgo de Guayaquil. Acta Oceanogr Pacifico 17:41-68

Cuevas JM, Martin JP, Bastida R (2006) Benthic community changes in a Patagonian intertidal: a forty years later comparison. Thalassas 22:29-37 
da Costa KG, Nalesso RC (2006) Effects of mussel farming on macrobenthic community structure in Southeastern Brazil. Aquaculture 258:655-667. doi:10.1016/j.aquaculture.2006. 04.023

Davis AR, Moreno CA (1995) Selection of substrata by juvenile Choromytilus chorus (Mytilidae): are chemical cues important? J Exp Mar Biol Ecol 191:167-180. doi: 10.1016/0022-0981(95)00049-W

Defeo O (2003) Marine invertebrate fisheries in sandy beaches: an overview. J Coast Res SI 35:56-65

Defeo O, Castilla JC (2005) More than one bag for the world fishery crisis and keys for comanagement successes in selected artisanal Latin American shellfisheries. Rev Fish Biol Fisheries 15:265-283. doi:10.1007/s11160-005-4865-0

Domaneschi O, Martins CM (2002) Isognomon bicolor (C. B. Adams) (Bivalvia, Isognomonidae): primeiro registro para o Brasil, redescrição da espécie e considerações sobre a ocorrência e distribuição de Isognomon na costa brasileira. Rev Bras Biol 19:601-610

Duarte C, Jaramillo E, Contreras H, Figueroa L (2006) Community structure of the macroinfauna in the sediments below an intertidal mussel bed (Mytilus chilensis (Hupe)) of Southern Chile. Rev Chil Hist Nat 79:353-368

Dudenhoefer D (2002) Balancing shrimp and mangroves in Ecuador. Available Online (http://www.eurocbc.org/ page 574.html). Accessed 24 July 2008

ECOLAP-MAE (2007) Guía del Patrimonio de Áreas Naturales Protegidas del Ecuador, ECOFUND, FAN, DarwinNet, IGM., Quito

FAO (1994) Manejo y Aprovechamiento Acuícola de Lagunas Costeras en América Latina y el Caribe. Trabajos presentados por Brasil, Colombia, Cuba, Mexico y Venezuela. AQUILA-Apoyo a las Actividades Regionales de Acuicultura para América Latina y el Caribe. Report No. 10

Fernández M, Jaramillo E, Marquet PA, Moreno CA, Navarrete SA, Ojeda FP, Valdovinos C, Vasquez J (2000) Diversidad, dinámica y biogeografía del ecosistema costero bentónico de Chile: revisión y bases para conservación marina. Rev Chil Hist Nat 73:797-830

Fernández J, Jiménez M, Allen T, Villafranca S (2007) Abundancia y riqueza de moluscos bivalvos del litoral rocoso, en cinco localidades del estado Sucre, Venezuela. Livro de Resumos-XII Congresso Latino-Americano de Ciências do Mar-XII COLACMAR: Abstract 4000870

Ferreira-Silva MAG, Barboza DF, Breves-Ramos A, Junqueira AOR (2007) Variação temporal da composição da comunidade invadida por Isognomon bicolor (Adams, 1845) na praia Vermelha, RJ. Livro de Resumos-XII Congresso Latino-Americano de Ciências do Mar-XII COLACMAR: Abstract 4000583

Fukuda JC, Mochel FR de AJCS, Castro ACL (2007) Mudanças na pesca de acordo com a percepção de pescadores artesanais no Município de Porto Rico Do Maranhão, MA, Brasil. Livro de Resumos-XII Congresso Latino-Americano de Ciências Do Mar-XII COLACMAR: Abstract 4000543

Gelcich S, Godoy N, Prado L, Castilla JC (2008) Add-on conservation benefits of marine territorial user rights fishery policies in Cental Chile. Ecol Appl 18:273-281. doi:10.1890/06-1896.1
Geller JB (1999) Decline of a native mussel masked by sibling species invasion. Conserv Biol 13:661-664. doi:10.1046/ j.1523-1739.1999.97470.x

Glaser M (2003) Interrelations between mangrove ecosystem, local economy and social sustainability in Caeté Estuary, North Brazil. Wetlands Ecol Manag 11:265. doi:10.1023/ A: 1025015600125

Glaser M, da Silva Oliveira R (2004) Prospects for the comanagement of mangrove ecosystems on the North Brazilian coast: Whose rights, whose duties and whose priorities? Nat Resour Forum 28:224-233. doi:10.1111/j. 1477-8947.2004.00092.x

Glynn PW (1988) El Nino-Southern Oscillation 1982-1983: nearshore population, community, and ecosystem responses. Annu Rev Ecol Syst 19:309-345

Grasso M (2000) Economic valuation of a mangrove ecosystem: understanding the linkages between local communities and mangroves, Caete River Bay (PA, Brazil). PhD Thesis, University of Maryland, College Park, USA

Guiñez R (2005) Una revisión del auto-raleo en mitílidos. Rev Biol Mar Oceanogr 40:1-16

Henriques MB, Marques HLdA, Pereira OM, Bastos GCC (2004) Aspectos da estrutura populacional do mexilhão Perna perna, relacionados à extração em bancos naturais da Baía de Santos, estado de São Paulo, Brasil. Bol Inst Pesca Sao Paulo 30:117-126

Hernández G, Defeo O (2005) Relación masa corporal-abundancia en un gremio de mitílidos suspensívoros del sublitoral rocoso de dos islas de Uruguay. Interciencia 30:711-716

Hockey P, Bosman A (1986) Man as an intertidal predator in Transkei: disturbance, community convergence and management of a natural food resource. Oikos 46:3-14. doi: $10.2307 / 3565373$

Jerardino A, Castilla JC, Ramirez JM, Hermosilla N (1992) Early coastal subsistence patterns in Central Chile: a systematic study of the marine-invertebrate fauna from the site of Curaumilla-1. S Am Antiq 3:43-62. doi:10.2307/ 971929

Jones CG, Lawton JH, Shachak M (1994) Organisms as ecosystem engineers. Oikos 69:373-386. doi:10.2307/354 5850

Juanicó M, Rodríguez-Moyano M (1976) Composición faunística de la comunidad de Mytilus edulis platensis d'Orbigny, 1846, ubicada a unas 55 millas al SE de La Paloma. Com Soc Malac Urug 4:113-116

Klappenbach MA (1965) Lista preliminar de los Mytilidae brasileños con claves para su determinación y notas sobre su distribución. An Acad Bras Cienc 37:327-351

Klink A (1991) The macrobenthic community in the southChilean Mytilus culture. Aquac Environ 14:171-172

Lasiak TA, Dye AH (1989) The ecology of the brown mussel Perna perna in Transkei: implications for the management of a traditional food resource. Biol Conserv 47:245257. doi:10.1016/0006-3207(89)90068-2

MARN (2000) Primer informe de país para la Convención sobre Diversidad Biológica, Ministerio del Ambiente y los Recursos Naturales (Venezuela)

Marques-Silva NS, Beasley CR, Paiva Gomes C, Lima Gardunho DC, Tagliaro CH, Schories D, Mehlig U (2006) Settlement dynamics of the encrusting epibenthic macrofauna in two 
creeks of the Caeté mangrove estuary (North Brazil). Wetlands Ecol Manag 14:67-78. doi:10.1007/s11273-0052568-X

McClanahan TR, Castilla JC, White AT, Defeo OD (2008). Healing small-scale fisheries by facilitating complex socio-ecological systems. Rev Fish Biol Fisheries. doi 10.1007/s11160-008-9088-8

Mckenzie CL, Troccoli L, Luis B (2003) History of the Atlantic Pearl-Oyster, Pinctacta imbricata, industry in Venezuela and Colombia, with biological and ecological observations. Mar Fish Rev 65:1-20

Moran MG (2004) Managing Wetlands for Global Change and Local Livelihoods. Case Study "Integral Use and Management of the Tumbes Mangroves". Report of the GBF17 Workshop on "Environmental Governance and Sustainable Development: The contribution to the RAMSAR Convention" 15-17 November 2002, Valencia

Moreno CA (1995) Macroalgae as a refuge from predation for recruits of the mussel Choromytilus chorus (Molina, 1782) in Southern Chile. J Exp Mar Biol Ecol 191:181193. doi:10.1016/0022-0981(95)00050-2

Moreno CA (2001) Community patterns generated by human harvesting on Chilean shores: a review. Aq Cons 11:1930. doi:10.1002/aqc.430

Moreno CA, Lunecke KM, Lepez MI (1986) The response of an intertidal Concholepas concholepas (Gastropoda) population to protection from man in Southern Chile and the effects on benthic sessile assemblages. Oikos 46:359364. doi: $10.2307 / 3565835$

Morsan EM (2003) Spatial analysis and abundance estimation of the southernmost population of purple clam Amiantis purpurata in Patagonia (Argentina). J Mar Biol Assoc UK 83:1073-1082. doi:10.1017/S0025315403008294h

Narvarte M, Gonzalez R, Filippo P (2007) Artisanal mollusk fisheries in San Matias Gulf (Patagonia, Argentina): an appraisal of the factors contributing to unsustainability. Fish Res 87:68-76. doi:10.1016/j.fishres.2007.06.012

Navarrete SA, Castilla JC (1993) Predation by Norway rats in the intertidal zone of central Chile. Mar Ecol Prog Ser 92:187-199. doi:10.3354/meps092187

Nishida AK, Nordi N, da Nóbrega Alves RR (2006) Mollusc gathering in Northeast Brazil: an ethnoecological approach. Hum Ecol 34:133-144. doi:10.1007/s10745005-9005-x

Norling P, Kautsky N (2007) Structural and functional effects of Mytilus edulis on diversity of associated species and ecosystem functioning. Mar Ecol Prog Ser 351:163-175

Ocampo-Thomason P (2006) Mangroves, people and cockles: impacts of the shrimp-farming industry on mangrove communities in Esmeraldas Province, Ecuador. In: Hoanh CT, Tuong TP, Gowing JW, Hardy B (eds) Environment and livelihoods in tropical coastal zones: managing agriculture-fishery-aquaculture conflicts. CAB International, UK, pp 140-153

Oliveira AM, Kjerfve B (1993) Environmental responses of a tropical coastal lagoon system to hydrological variability: Mundau-Manguaba, Brazil. Estuar Coast Shelf Sci 37:575-591. doi:10.1006/ecss.1993.1074

Oliveira MEGCd, Russo CAM, Lazoski C, Vianna PRFG, Solé-Cava AM (2005) Genetic variation and population structure of two species of neo-tropical mud-mussels (Mytella spp.). Genet Mol Res 4:197-202

OSPAR Commission (2005) Case Reports for the Initial List of Threatened and/or Declining Species and Habitats in the OSPAR Maritime Area. Biodiversity Series: OSPAR Commission. Available online (http://www.ospar.org). Accessed 24 July 2008

PADESPA (2003) Estudio Socio-económico de la actividad extractiva del Choro, Pisco, Perú

Paine RT, Castillo JC, Cancino J (1985) Perturbation and recovery patterns of starfish-dominated intertidal assemblages in Chile, New Zealand, and Washington State. Am Nat 125:679-691. doi:10.1086/284371

Pastor de Ward CT (2000) Polychaete assemblages in the San José Gulf (Chubut, Argentina), in relation to abiotic and biotic factors. Mar Ecol (Berl) 21:175-190. doi:10.1046/ j.1439-0485.2000.00704.x

Penchaszadeh PE (1973) Ecología de la comunidad del mejillín (Brachydontes rodriguezi d'Orb.) en el mediolitoral rocoso de Mar del Plata (Argentina): el proceso de recolonización. Physis, Sección A 32:51-64

Pereira OM, Hilberath RC, Ansarah PRAC, Galvão MSN (2003) Estimativa da produção de Mytella falcata e de $M$. guyanensis em bancos naturais do estuário de Ilha Comprida-Sp-Brasil. Bol Inst Pesca Sao Paulo 29:139-149

PISCO (2008) The Science of Marine Reserves (Latin American and the Caribbean), 2nd edn, 22 pp. www.piscoweb. org. Accessed 24 July 2008

Prado L, Castilla JC (2006) The bioengineer Perumytilus purpuratus (Mollusca: Bivalvia) in central Chile: biodiversity, habitat structural complexity and environmental heterogeneity. J Mar Biol Assoc UK 86:417-421. doi: 10.1017/S0025315406013282

Prieto A, Cruz T, Ruiz LJ, García N (1999a) Moluscos asociados a sustratos someros en la Laguna de Bocaripo, Estado Sucre, Venezuela. Bol Cent Invest Biologicas Maracaibo 40:1-15

Prieto AS, Flores MS, Lodeiros C (1999b) Madurez sexual e índice de condición en una población del Mejillón de fondo Modiolus squamosus (mollusca, bivalvia) en Tocuchare, Golfo de Cariaco, Venezuela. Ecotropicos 12:83-90

Prieto A, Nuñez M, García N, Velásquez F, Marcano J, Lodeiros C (2007) Biomasa de bancos de moluscos en la Península de Paria, noreste de Venezuela. XII Congresso Latino-Americano de Ciências do Mar-XII COLACMAR Abstract 4000876

Quijón P, Jaramillo E, Pino M (1996) Macroinfaunal assemblages associated with mussel and clam beds in an estuary of Southern Chile. Estuaries 19:62-74. doi:10.2307/ 1352652

Riestra G, Defeo O (2000) La comunidad macrobentónica asociada al mejillon Mytilus edulis platensis en costas del departamento de Maldonado: variación espacio-temporal e incidencia del impacto pesquero. In: Rey M (ed) Recursos pesqueros no tradicionales: moluscos bentónicos marinos. Proyecto URU/92/003. INAPE-PNUD, Montevideo, pp 17-57

Rios EC (1994) Seashells of Brazil, 2nd edn. Fundação Universidade de Rio Grande, Museu Oceanográfico, Rio Grande do Sul 
Ríos C, Mutschke E (1999) Community structure of intertidal boluder-cobble fields in the Strait of Magellan, Chile. Sci Mar 63(1):193-201

Rius M, Cabral H (2004) Human harvesting of Mytilus galloprovincialis Lamarck, 1819, on the central coast of Portugal. Sci Mar 68:545-551

Rius M, Zabala M (2008) Are marine protected areas useful for the recovery of the Mediterranean mussel populations? Aquat Conserv Mar Freshwat Ecosyst 18:527-540. doi: $10.1002 /$ aqc. 887

Saint-Paul U (2006) Interrelations among mangroves, the local economy and social sustainability: a review from a case study in North Brazil. In: Hoanh CT, Tuong TP, Gowing JW, Hardy B (eds) Environment and livelihoods in tropical coastal zones: managing agriculture-fishery-aquaculture conflicts. CAB International, UK, pp 154-162

Sala E, Aburto-Oropeza O, Paredes G, Parra I, Barrera JC, Dayton PK (2002) A general model for designing networks of marine reserves. Science 298:1991-1993. doi: $10.1126 /$ science. 1075284

Sanchez V (2002) Crece la industria mitilicultora. Aquanoticias 75

Scarabino V (1977) Moluscos del Golfo San Matías (Provincia de Río Negro, República Argentina). Inventario y claves para su identificación. Com Soc Malac Urug 4:177-285

Scarabino F, Menafra R, Etchegaray P (1999) Presencia de Rapana venosa (Valenciennes, 1846) (Gastropoda: Muricidae) en el Río de la Plata. Boletín de la Sociedad Zoológica del Uruguay (Actas de las V Jornadas de Zoología del Uruguay) 11 (Segunda Epoca)

Scarabino F, Zaffaroni JC, Clavijo C, Carranza A, Nin M (2006) Bivalvos marinos y estuarinos de la costa uruguaya: faunística, distribución, taxonomía y conservación. In: Menafra R, Rodríguez-Gallego L, Scarabino F, Conde $\mathrm{D}$ (eds) Bases para la conservación y el manejo de la costa uruguaya. Vida Silvestre (Sociedad Uruguaya para la Conservación de la Naturaleza), Montevideo, pp 157-169

Scelzo MA, Elias R, Vallarino EA, Charrier M, Lucero N, Alvarez F (1996) Variación estacional de la estructura comunitaria del bivalvo Brachydontes rodriguezi (d'Orbigny, 1846) en sustratos artificiales (Mar del Plata, Argentina). Neritica 10:87-102

Smaal AC (1991) The ecology and cultivation of mussels: new advances. Aquaculture 94:245-261. doi:10.1016/00448486(91)90121-M

Soenens P (1985) Estudios preliminares sobre el efecto del fenómeno "El Niño" 1982-1983 en comunidades de Aulacomya ater. In: Arntz WE, Landa A, Tarazona J (eds) El fenómeno El Niño Su impacto en la fauna marina. Boletín del Instituto del Mar del Perú, Callao, pp 51-53

Sullivan K, Bustamante G (1999) Setting geographic priorities for marine conservation in South America and the Caribbean. The Nature Conservancy, Arlington

Tanaka MO (2005) Recolonization of experimental gaps by the mussels Brachidontes darwinianus and B. solisianus in a subtropical rocky shore. Braz Arch Biol Tech 48:115-119
Tanaka MO, Magalhães CA (2002) Edge effects and succession dynamics in Brachidontes mussel beds. Mar Ecol Prog Ser 237:151-158. doi:10.3354/meps237151

Thiel M, Ullrich N (2002) Hard rock versus soft bottom: the fauna associated with intertidal mussel beds on hard bottoms along the coast of Chile, and considerations on the functional role of mussel beds. Helgol Mar Res 56:2130. doi:10.1007/s10152-001-0098-3

Tokeshi M, Romero L (1995) Filling a gap: dynamics of space occupancy on a mussel-dominated subtropical rocky shore. Mar Ecol Prog Ser 119:167-176. doi:10.3354/meps 119167

Toro JE, Alcapán AC, Ojeda JA, Vergara AM (2004) Response to genetic selection for growth rate in juveniles of Ostrea chilensis Philippi (Bivalvia: Ostreidae), maintained under laboratory conditions. Rev Biol Mar Oceanogr 39:53-59

Valdivia N, Thiel M (2006) Effects of point-source nutrient addition and mussel removal on epibiotic assemblages in Perumytilus purpuratus beds. J Sea Res 56:271-283. doi: 10.1016/j.seares.2006.06.003

Vallarino EA, Rivero MS, Gravina MC, Elías R (2002) The community-level response to sewage impact in intertidal mytilid beds of the Southwestern Atlantic, and the use of the Shannon index to assess pollution. Rev Biol Mar Oceanogr 37:25-33

Villafranca S, Jiménez M (2006) Comunidad de moluscos asociados al mejillón verde Perna viridis (Mollusca: Bivalvia) y sus relaciones tróficas en la costa norte de la península de Araya, Estado Sucre, Venezuela. Rev Biol Trop 54(suppl. 3):135-144

Winter JE, Toro JE, Navarro JM, Valenzuela GS, Chaparro OR (1984) Recent developments, status and prospects of molluscan aquaculture on the Pacific coast of South America. Aquaculture 39:95-134. doi:10.1016/00448486(84)90261-8

Wolff WJ (2005) The exploitation of living resources in the Dutch Wadden Sea: a historical overview. Helgol Mar Res 59:31-38. doi:10.1007/s10152-004-0204-4

Wood AR, Apte S, MacAvoy ES, Gardner JPA (2007) A molecular phylogeny of the marine mussel genus Perna (Bivalvia: Mytilidae) based on nuclear (ITS1\&2) and mitochondrial (COI) DNA sequences. Mol Phyl Evol 44:685-698. doi:10.1016/j.ympev.2006.12.019

Zaixso H (1999) Distribución submareal del mitílido Aulacomya atra atra (Molina) en el golfo San José (Argentina) en relación a la profundidad, características del fondo y condiciones hidrográficas. Physis 57:1-10

Zaixso HE (2004) Bancos de cholga Aulacomya atra atra (Molina) (Bivalvia: Mytilidae) del golfo San José (Chubut, Argentina): Diversidad y relaciones con facies afines. Rev Biol Mar Oceanogr 39:61-78

Zaixso H, Lizarralde Z, Pastor C, Gomes-Simes E, Romanello E, Pagnoni G (1998) Spatial distribution of subtidal macrozoobenthos from San Jose Gulf (Chubut, Argentine). Rev Biol Mar Oceanogr 33:43 